\title{
Problemets anatomi - Fra ledelsesproblem til vidensproblem
}

\section{PROBLEMFORMULERING • VIDENSPROBLEM • \\ LEDELSESPROBLEM • PROBLEMORIENTERET PROJEKTARBEJDE • MASTERAFHANDLING • METODE}




\title{
Problemets anatomi - Fra ledelsesproblem til vidensproblem
}

\author{
PROBLEMFORMULERING • VIDENSPROBLEM • \\ LEDELSESPROBLEM • PROBLEMORIENTERET \\ PROJEKTARBEJDE • MASTERAFHANDLING • METODE
}

Formålet med denne artikel er at bidrage til forståelsen af, hvordan praktiske problemer (herunder ledelsesproblemer) og vidensproblemer er forskellige og alligevel kan berige hinanden. Artiklen henvender sig til ledere, som skal lave en akademisk problemorienteret opgave i samfundsvidenskabeligt regi. Man benytter sig her ofte af problemorienteret projektarbejde, dvs at man strukturerer sine analyser ved hjælp af en problemformulering. Artiklen stiller - og besvarer - derfor spørgsmålet om, hvad et problem er. Endvidere argumenterer den for vigtigheden af at skelne mellem vidensog ledelsesproblemer.

Artiklen består af tre dele. 1) Først beskriver vi, hvad der i hverdagssproget gør et problem til et problem, altså problemets anatomi. I forlængelse af det beskriver vi, hvad der kendetegner henholdsvis ledelses- og vidensproblemer som særlige typer af problemer. 2) Dernæst argumenterer vi for, at problemer ikke er givet som sådan. Et problem er kun et problem i rammerne af en særlig meningsmæssig kontekst. 3) Afslutningsvist formulerer vi fem tommelfingerregler for, hvordan man som studerende på lederuddannelser kan arbejde konkret med at lave koblinger mellem ledelses- og vidensproblemer. 


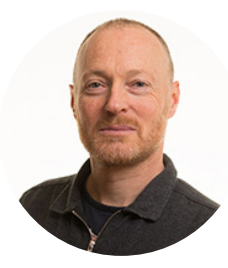

\section{Morten Knudsen}

Morten Knudsen er lektor i organisationsanalyse på Institut for Organisation, CBS. Med fokus på offentlige organisationer og med kommunikationsteoretiske perspektiver har han bl.a. forsket i beslutningsprocessers dynamikker og i, hvordan organisationer ignorerer ubekvem information og egen uvidenhed. Pt er han involveret $\mathrm{i}$ et forskningsprojekt om ledelsesudviklingsprogrammers organisatoriske betydning. Han har endvidere undervist i samfundsvidenskabelig metode på MPG siden 2011, ligesom han har vejledt talrige masterafhandlinger.

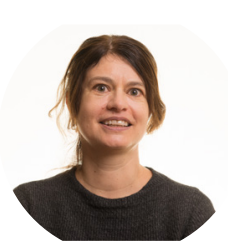

\section{Lise Justesen}

Lise Justesen er lektor på Institut for Organisation, CBS. Hun forsker bl.a. i ledelsesteknologier og organisation og er på nuværende tidspunkt i gang med et forskningsprojekt om digitalisering i den offentlige sektor. Hun har desuden en interesse i kvalitative metoder og har skrevet om dette i flere lærebøger. Hun har undervist i samfundsvidenskabelig metode på MPG siden 2011 og har stor erfaring med vejledning af masterafhandlinger. 


\section{Indledning}

Denne artikel handler om problemer og om, hvordan vi forstår problemer. Baggrunden er flere års erfaring som undervisere på CBS' masteruddannelser for ledere, hvor problemorienteret arbejde er et vigtigt pædagogisk element. Det vil sige, at begrebet problem står centralt i undervisningen. Det gør det på den ene side, fordi ledere er optagede af forskellige ledelsesproblemer i deres organisationer. Det kan dreje sig om højt sygefravær i organisationen, oplevelse af dårligt samarbejde og forfejlet kommunikation mellem afdelinger eller manglende organisatorisk tilslutning til de senest lancerede ledelsestiltag som $\mathrm{fx}$ lean, brugerinddragelse eller en ny strategi. Denne type ledelsesproblemer udgør både en væsentlig kontekst for og drivkraft i undervisningen. Men på den anden side er problembegrebet også centralt i en akademisk sammenhæng, hvor problemer ikke i sig selv peger på, at der er noget galt, som skal forandres. Akademiske undersøgelser søger at skabe ny viden inden for et givent område. Formålet er i denne sammenhæng produktion af viden snarere end handlingsanvisende løsninger på praktiske problemer, selvom den viden, der fremkommer på baggrund af undersøgelser, i nogle tilfælde kan danne grundlag for praktiske handlingsanvisninger. Der er med andre ord en begrebsmæssig forskel på det, vi i hverdagssproget - herunder i vores ledelsespraksis - omtaler som problemer og så det, vi i en akademisk sammenhæng kan kalde vidensproblemer.

Som undervisere har vi oplevet, at det kan være vanskeligt både at skelne mellem og på frugtbar vis at få kombineret ledelsesmæssige problemer og vidensproblemer. Det er både forståeligt og ganske legitimt, at ledere umiddelbart er mere optaget af ledelsesproblemer end af vidensproblemer. For en studerende på en lederuddannelse er kunsten derfor ofte at få gjort løsningen af sit vidensproblem relevant for løsningen af sit ledelsesproblem. Det lyder måske enkelt, men det er det sjældent. Når det kan være vanskeligt at komme i gang med sit projekt i en uddannelsesmæssig sammenhæng, så kan det hænge sammen med en tilbøjelighed til at formulere sin problemformulering som et ledelsesproblem. Når det sker, forsvinder distinktionen mellem de to problemtyper, og det betyder, at man ikke får gjort det tydeligt, hvilket vidensproblem, man vil arbejde med.

Når man som leder tager en akademisk forankret lederuddannelse, spiller ledelsesproblemer en vigtig rolle i forhold til beslutningerne om, hvad man skriver $\mathrm{fx}$ sin masterafhandling om. Men samtidigt er det også klart, at udarbejdelsen af en akademisk opgave og besvarelsen af dens problemformulering ikke i sig selv løser et ledelsesproblem. Når ledelsesproblemer og vidensproblemer således ikke er identiske, hvordan får man dem så alligevel til at hænge sammen på en meningsfuld måde? Det er ambitionen, at denne artikel kan hjælpe med til at håndtere den udfordring. Vi vil argumentere for, hvorfor man ikke gennem videnskabelig problemløsning kan sige, hvordan man løser sine ledelsesmæssige problemer. Men vi vil også komme med nogle bud på, hvordan man alligevel kan bestræbe sig på at kvalificere løsningen af sine ledelsesmæssige problemer gennem løsningen af videnskabelige problemer.

Vores skelnen mellem videns- og ledelsesproblemer betyder ikke, at der ikke findes blandingsformer, hvor det kan forekomme kunstigt at ville skelne skarpt mellem dem. Fx er aktionsforskning og anden praksisnær forskning (ligesom nogle typer af naturvi- 
denskabelig-teknisk forskning) karakteriseret ved netop at sigte på praksis og løsningen af praktiske problemer. Vores skelnen mellem videns- og ledelsesproblemer skal derfor ikke ses som en universel, men som en pragmatisk skelnen. Vi mener med andre ord, at det er en skelnen, som er brugbar og hensigtsmæssig i en sammenhæng, hvor ledere (som er vant til at arbejde med praktiske problemer) skal arbejde med vidensmæssige problemer i en akademisk kontekst - som $\mathrm{fx}$ en masteruddannelse i offentlig ledelse. I artiklen reflekterer vi over, hvordan begrebet problem kan forstås som et begreb med flere betydninger, der analytisk set er forskellige, men i praksis kan forbindes på måder, så de beriger både det akademiske og det ledelsesmæssige arbejde.

\section{Selv om ledere på masteruddannelser til stadighed omgås problem- er $\mathrm{i}$ form af ledelsesproblemer på deres arbejdsplader og problem- stillinger og problemformuleringer i akademisk sammenhæng på deres uddannelse, så bliver det sjældent diskuteret, hvad der gør problemet til et problem.}

Ved at dissekere problemet og beskrive dets anatomi håber vi at kunne levere nogle begrebsafklaringer og distinktioner, som er anvendelige i arbejdet med specifikke ledelses- og vidensproblemer. Når vi taler om 'problemets anatomi' er det altså med henblik på at få en bedre forståelse for ledelsesmæssige og videnskabelige problemer. Det er ikke hensigten at diskutere, hvordan disse problemer forholder sig til andre typer af problemer som fx filosofiske og etiske problemer.

At beskrive sit ledelsesproblem så konkret som muligt kan være en hjælp i forhold til at afgøre, hvad man producerer viden om, altså hvilket vidensproblem, man arbejder med. Som studerende kan man også slippe for nogle frustrationer ved at blive bevidst om forskellen mellem ledelses- og vidensproblemer. Det er samtidig en skelnen, som gør det muligt at reflektere over, hvordan de forskellige typer af problemer kan berige hinanden. Læseren skal ikke forvente en bred fremstilling af emner relateret til problemformuleringer i akademiske opgaver. Her kan vi i stedet henvise til udmærkede fremstillinger i fx Pedersen (2015).

Artiklen består af tre dele. 1) Først beskriver vi, hvad der i hverdagssproget gør et problem til et problem, altså problemets anatomi. I forlængelse af det beskriver vi, hvad der kendetegner henholdsvis ledelses- og vidensproblemer som særlige typer af problemer. 2) Dernæst argumenterer vi for, at problemer ikke er givet som sådan. Et problem er kun et problem i rammerne af en særlig meningsmæssig kontekst. 3) Afslutningsvist formulerer vi fem tommelfingerregler for, hvordan man som studerende på lederuddannelser kan arbejde konkret med at lave koblinger mellem ledelses- og vidensproblemer.

\section{Problemets anatomi}

Problem er et af de begreber, som vi ofte bruger i hverdagssproget, men som i det øjeblik vi skal definere det, viser sig at være mere komplekst, end vi måske troede. I dette afsnit dissekerer vi begrebet $i$ tre dele og viser samtidig, hvordan de tre dele hænger sammen. Det fremstår muligvis en smule tørt og formalistisk, men det er nyttigt i forhold 
til diskussioner af problemformuleringer og forholdet mellem ledelses- og vidensproblemer.

Vi tager afsæt i en antagelse om, at begrebet problem er baseret på tre elementer: a) en uønsket aktuel situation (inklusiv en foregribelse af hvordan den aktuelle situation vil præge fremtiden), b) et ønske om, hvordan fremtiden skal se ud og c) en barriere som forhindrer, at den aktuelle situation transformerer sig til den ønskede fremtidige tilstand (Agre, 1982, Schmidt, 2011: 259 f, Smith, 1989). Dette kan illustreres med et simpelt eksempel: a) situation: min cykel er låst, b) ønske om fremtiden: jeg vil gerne cykle en tur, c) barriere for realisering af ønsket fremtid: jeg kan ikke finde min cykelnøgle. Derfor har jeg et problem. Hver for sig udgør elementerne ikke et problem. Nogle gange er det fx godt, at cyklen er låst, og andre gange er det irrelevant, at jeg ikke kan finde nøglen.

\section{Det er kombinationen af en uønsket situation, en ønsket situation og en vanskelighed i at transformere den uønskede til den ønskede situation, som tilsammen udgør et problem.}

I den forstand er der altid noget galt, når vi taler om problemer i hverdagssproget. Booth og hans kollegaer kalder den type problemer for praktiske problemer og definerer dette begreb på følgende måde:

"A practical problem is caused by some condition in the world, from email spam to terrorism, that makes us unhappy because it costs us time, money, respect, security, pain, even our lives. You solve a practical problem by doing something that changes the world by eliminating the causes that lead to its cost, or by encouraging others to do so (Booth et al., 2003: 59).

Et praktisk problem handler dermed om en uønsket tilstand, som man gerne vil ændre. Løsningen består i at foretage - eller iværksætte - handlinger, der har dette formål. I denne forståelse er problemer altid negative i den forstand, at de netop er uønskede tilstande, som de berørte personer gerne vil ændre. De opleves som omkostningsfulde for os. Det, der gør noget til et problem i denne betydning, er, at der ligger en vanskelighed i transformationen fra den uønskede til den ønskede tilstand.

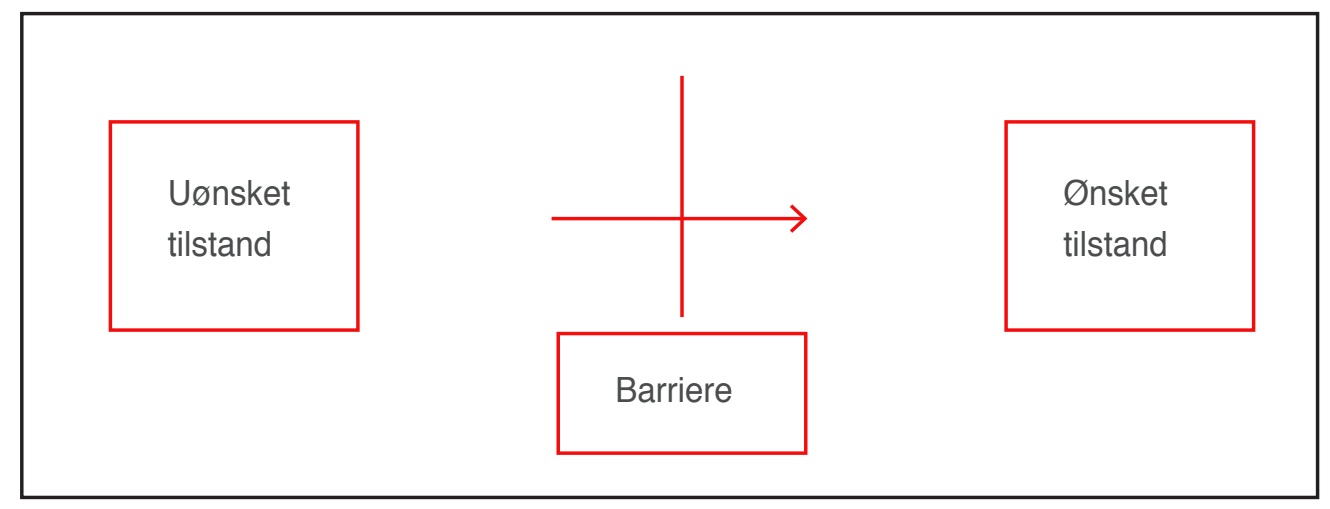

Figur 1. Problemets anatomi 
Et problem i hverdagsbetydningen er således et praktisk problem, der består af en specifik situation med en uønsket tilstand, en ønsket tilstand og en barriere for at transformere den uønskede til den ønskede tilstand. Problemet er enheden af disse tre elementer.

For at gøre det klarere hvad vi mener, kan vi markere nogle grænsetilfælde. Hvis vi har en uønsket tilstand, men ikke kan pege på en mulig ønsket tilstand, eller det forekommer umuligt at nå en ønsket tilstand (hvis barrieren er uigennemtrængelig), så er der ikke tale om et problem, men om et vilkår. I den betydning er det fx ikke et problem, at der ikke er uendelige ressourcer til rådighed i verden. Det er et vilkår. For at noget kan betragtes som et problem, så må der være en mulig transformation fra den ønskede tilstand til noget andet. Et andet tilfælde er der, hvor der ikke er en barriere for transformationen, eller hvor barrieren er betydningsløs. I det tilfælde er der ikke tale om et problem, men en opgave, hvor vi ved, hvordan vi skal transformere den uønskede til den ønskede tilstand og samtidig har midlerne til det. Vi løser hele tiden opgaver (holder MUS, laver vagtplaner, svarer på mails, deltager i koordinerende møder osv.). At kalde alle disse opgaver for problemer ville være at tabe en mulighed for sproglig præcision. Forskellen mellem at løse en opgave og at løse et problem er, at problemløsningen og dermed transformationen fra uønsket til ønsket tilstand er forbundet med en vanskelighed.

\section{Distinktionen mellem problemer, vilkår og opgaver er væsentlig, men også en distinktion, der både kræver analyse, fortolkning og diskussion. Det er ikke givet på forhånd, hvor grænserne går.}

Hvor man med ovenstående definition af problemets tre elementer kan tænke mange forskellige typer af barrierer, der viser Scholz (2011), hvordan manglende viden også kan være en vigtig barriere i et problem. Kombinationen af uønsket situation og en $ø n s k e t$ fremtid er ikke i sig selv nok til, at noget er et problem. Vi er uophørligt konfronteret med uønskede situationer (situation: skraldespanden er fuld; ønske om fremtiden: at jeg kan lægge affald i den), som ikke kvalificerer sig til at være problemer, i hvert fald ikke interessante problemer, som fortjener overvejelse. Hvis skraldespanden er fuld, så skal den blot tømmes. For at en uønsket situation bliver til et problem kræver det, at vi ikke ved, hvordan man transformerer den uønskede situation til den ønskede situation. Det er manglende viden om, hvordan man transformerer den uønskede situation til den ønskede situation, som gør problemet til et problem. Det kræver en mangel på transformationsviden, som kan facilitere den uønskede situations overførsel til den ønskede situation (Scholz, 2011: 403). I forhold til skraldespanden: at den er fyldt vil være et problem, hvis jeg har brækket begge arme og ikke ved, hvordan jeg skal bære den.

Inspireret af Scholz' begreb om transformationsviden kan vi indføre en handlingsmæssig pendant og tale om transformationshandling. Transformationshandling er den handling, som sigter mod at overvinde barriererne for at bevæge sig fra den uønskede til den ønskede tilstand. Her kan man hævde, at denne transformationshandling må være forbundet med vanskeligheder for, at der er tale om et problem. Det kan være, fordi handlingen kræver nogle ressourcer, at det kan være vanskeligt at mobilisere. Men det kan også være, fordi handlingen risikerer at medføre nogle andre uønskede effekter. 
Hvis transformationshandlingen i sig selv indebærer eller skaber en uønsket situation, er der samlet set tale om et problem.

\section{Ledelsesproblemer}

Ud fra ovenstående model kan vi nu karakterisere det særlige ved henholdsvis ledelses- og vidensproblemer. Vi tager afsæt i nogle eksempler på ledelsesproblemer, som er formuleret af masterstuderende på ledelsesuddannelserne som et første bud på en problemformulering, de gerne vil arbejde videre med på studiet.

\section{Eksempel 1:}

Hvordan kan vi som ledelse under de givne styringsvilkår gore de professionelle arbejdsfællesskaber meningsfulde og værdifulde for medarbejderne?

Denne formulering begynder med en beskrivelse af den ønskede tilstand, mens den uønskede tilstand ikke fremgår direkte af problemformuleringsudkastet, men er beskrevet som baggrund for problemformuleringen. Vi ser her, at den givne måde at styre på bliver sat som et vilkår - "styringsvilkår" - hvilket vil sige, at det bliver set som en konstant. Det vil sige, at det bliver irrelevant, om styringsvilkårene er en ønsket eller uønsket tilstand i denne sammenhæng. Den uønskede tilstand i denne specifikke situation - set fra lederens perspektiv - handler i stedet om, at medarbejderne har problemer med at finde mening i et stadigt mere styret og effektiviseret arbejdsliv. Som ordene 'kan gøre' i problemformuleringen indikerer, så kræver en løsning af problemet en transformationshandling, hvor nogle barrierer overvindes. Men en vigtig dimension $\mathrm{i}$ problemet er, at ledelsen ikke ved, hvad den skal gøre. Problemet er med andre ord formuleret som et praktisk problem, som et ledelsesproblem, der kalder på handling. Men samtidigt implicerer det også et vidensproblem. For at løse problemet skal man gøre noget, men man skal også vide, hvad man skal gøre, hvilket illustrerer, at ledelsesproblemer og vidensproblemer ofte er sammenvævede i praksis.

\section{Eksempel 2:}

Hvordan kan organisationen ledelsesmæssigt med afsæt i den narrative praksis omforme de dominerende problemfortællinger, så medarbejderne i den nye afdeling får fokus på de mere foretrukne og mulighedsskabende fortællinger ved fremtiden?

I dette eksempel består den uønskede tilstand ifølge lederen i, at medarbejderne 'ser problemer i stedet for muligheder'. Den ønskede tilstand er, at medarbejderne taler om fremtiden på en mere positiv måde. Igen er der tale om et problem, der er formuleret som ledelsesproblem, men samtidig knytter an til et implicit vidensproblem. Ledelsen må gøre noget, den må handle for at transformere 'de dominerende problemfortællinger' til de ønskede 'mulighedsskabende fortællinger'. Men spørgsmålet er, hvad ledelsen skal gøre. Igen ser vi, at en del af barrieren for at transformere uønsket til ønsket situation er, at ledelsen ikke ved, hvad den skal gøre for at etablere denne transformation.

Vi har gennem vores undervisning på CBS' masteruddannelser for ledere set utallige udkast til problemformuleringer, som ligner de to eksempler og begynder med tilsvaren- 
de formuleringer i form af "hvordan kan vi...". Det er spørgsmål, som stilles af ledere, som har en idé om, at de vil gøre noget ved et problem, men hvor de ikke ved, hvad de skal gøre. Dermed er det problemer, som både peger på transformationsviden (barrieren er manglende viden om, hvordan vi transformerer den uønskede til den ønskede tilstand) og på transformationshandling (en overvindelse af barrieren kræver en handling, som af forskellige grunde er forbundet med vanskeligheder). Vores nedslående kommentar til denne type "hvordan kan vi..." problemformuleringer er som regel, at det på den ene side er et som oftest ganske forståeligt ønske, men at det spørgsmål på den anden side ikke umiddelbart kan besvares med videnskabelige metoder. For at forstå det skal vi nu gå over til at skitsere strukturen i det, vi kalder vidensproblemer.

\section{Vidensproblemer}

I en akademisk sammenhæng arbejder man med problemer, der relaterer sig til viden. Konklusionen i en masterafhandling består ikke i en handling, men i udsagn om, hvad der er tilfældet, hvordan et givent fænomen forstås i en særlig kontekst, eller hvad der ligger bag det pågældende fænomen. Man har med andre ord produceret viden - og altså løst et vidensproblem. Hvor løsningen af et ledelsesproblem fuldbyrdes med en handling, så fuldbyrdes løsningen af et vidensproblem med ny viden.

Generelt kan vi sige, at det uønskede i en videnskabelig kontekst er uvidenhed, mens det ønskede er viden. Barrieren er så de forhold, som gør det vanskeligt at transformere uvidenhed til viden. Det kan fx være, at vi ikke har empirisk materiale, der gør det muligt at etablere viden. Dermed bliver produktionen af data nødvendigt. Det kan også være, at vores begrebslige reservoir er for begrænset eller irrelevant i forhold til at forstå det fænomen, vi undersøger. Det kan fx være, at vi som psykologer ikke har teoretiske begreber for politiske kampe og kollektive aktører og derfor ikke forstår de konflikter, som præger en given organisation. Eller det kan være, at vi som sociologer ikke har blik for de individuelle identitetsprojekter, som medarbejderne er involveret i. Strukturelt er der dermed klare paralleller mellem praktiske problemer, herunder ledelsesproblemer, på den ene side og vidensproblemer på den anden side. Det kan vi illustrere med følgende figur:

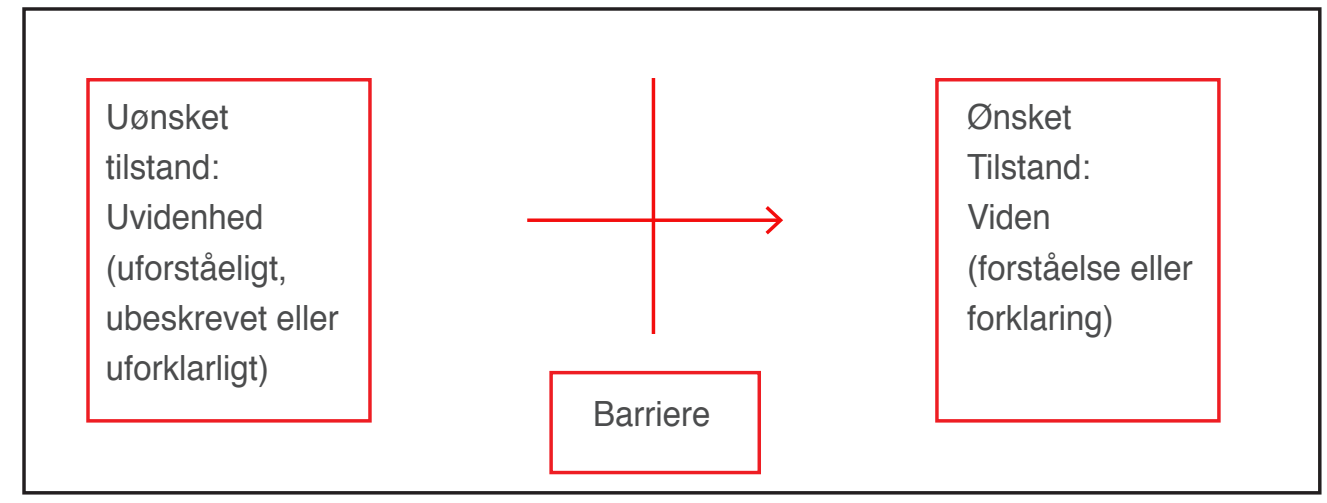

Figur 2: Et vidensproblem

Figur 2 viser elementerne i et vidensproblem og illustrerer, at der også her er en spænding mellem to tilstande, der står centralt. Drivkraften er en oplevelse af "uvidenhed" - at der er noget, vi ikke kan forstå, men gerne vil forstå. I 1905 så den østrigske filosof Ernst Mach det centrale i problemet som en inkongruens mellem tanke og kendsgernin- 
ger såvel som mellem tanker indbyrdes. Her ligger den uønskede tilstand altså i, at vi kan iagttage noget, som ikke stemmer med vores forestillinger om, hvordan det burde være (Mach, 1905/2015: 252). Den ønskede tilstand består så i kongruens mellem vores forestillinger, og hvad vi iagttager. Også videnskabsfilosoffen Karl Popper giver problemer en central placering i det videnskabelige arbejde:

Yet science starts only with problems. Problems crop up especially when we are disappointed in our expectations, or when our theories involve us in difficulties, in contradictions [...]. It is the problem which challenges us to learn; to advance our knowledge; to experiment; and to observe. (Popper, 1972: 301 ).

Som hos Mach ligger det uønskede i det videnskabelige problem ifølge Popper i tankemæssige modsigelser eller $\mathrm{i}$ et mismatch mellem vores forventninger (i form af teorier) og så vores iagttagelser.

Den amerikanske filosof John Dewey argumenterer netop for, at vi kan udvide betydningen af begrebet problem, så det har denne betydning: "... if we are willing to extend the meaning of the word problem to whatever - no matter how slight and common place in character - that perplexes and challenges the mind..." (Dewey, 1910/2012: 9).

\section{I den forstand udspringer vidensproblemer først og fremmest af en undren - eller med det, Alvesson og Kärreman med en mere drama- tisk formulering kalder et "forståelsesmæssigt sammenbrud" (Alves- son og Kärreman, 2005: 128).}

Disse sammenbrud leder til det, der metaforisk kan beskrives som mysterier (ibid.) eller typologiseres som fx paradokser, anomalier eller nomalier (Pedersen, 2015).

De tekster af videnskabsfilosoffer og øvrige teoretikere, vi har refereret til ovenfor, spænder ikke blot over mere end et århundrede, men repræsenterer også vidt forskellige videnskabsteoretiske positioner, der på mange måder er i indbyrdes strid med hinanden. Mach var forløber for den logiske positivisme, Popper rubriceres gerne som kritisk rationalist, Dewey var med til at udvikle og definere den amerikanske pragmatisme, mens organisationsteoretikerne Alvesson og Kärreman er inspireret af konstruktivisme og critical management studies. Men til trods for væsentlige forskelle peger de alle i samme retning, når det drejer sig om at udpege problemer som et væsentligt omdrejningspunkt i videnskabeligt arbejde og at definere problemer i denne sammenhæng på en måde, der adskiller sig fra praktiske problemer, som man støder på i sin hverdag.

Problemer er det, som holder videnskaben i gang. Samtidig med, at videnskaben lever af problemer, så er det en kvalitet ved et videnskabeligt problem, at det gør ondt, fordi der er en barriere for at transformere uvidenhed til viden. Det er således typisk en kvalitet ved et forskningsmæssigt spørgsmål, at det er vanskeligt at svare på - at det altså er et problem. Det skal lægge op til en videnstransformation, som kan overraske, dvs. hvor man ikke på forhånd ved, hvad svaret vil være. I den forstand knytter der sig forskellige gyldighedskrav til de to typer af problemer. Ifølge Alvesson og Kärreman er gode videnskabelige problemer kendetegnet ved at være interessante og ved at 
"indbefatte et stort potentiale for empirisk respons og for ny indsigt, der udgør en betydningsfuld tilføjelse til - eller indsigelse imod - den foreliggende viden" (Alvesson og Kärreman, 2005: 123).

Mens praktiske problemer således er noget, vi helst vil undgå, så er vidensproblemer noget, vi aktivt søger efter for at kunne lave interessante undersøgelser og dermed frembringe ny viden (i første omgang for sig selv og i anden omgang muligvis også for andre). Det har den konsekvens, at vidensproblemer ikke behøver tage udgangspunkt $\mathrm{i}$, at der er noget galt i fx vores organisation. For spørgsmålet bliver ikke mindst, hvordan man etablerer sin uvidenhed, dvs. hvordan man etablerer et godt problem. Der kan således ligge meget arbejde $i$ at finde et godt problem, dvs. et problem, som man finder værd at undersøge.

En basal fordring i videnskabeligt arbejde består i at finde et godt problem og formulere det på en måde, så det lader sig undersøge akademisk. Og egentlig er det misvisende at tale om at finde problemer, fordi det synes at forudsætte, at problemer så at sige ligger helstøbte og klar derude til at blive fundet, samlet op og løst. Det er ikke tilfældet, for problemer byder ikke sig selv til uden videre. Det kræver altid tankearbejde at identificere, afgrænse og formulere et godt problem. Videnskab handler i den forstand om at løse selvskabte problemer. Den tyske sociolog Max Weber formulerede det således: "Det, der danner basis for videnskabernes arbejdsområde er ikke 'saglige' sammenhænge mellem "ting", men tankemæssige sammenhænge mellem problemer..." (Weber, 1904/2003: 84). Det vil sige, at problemidentifikationer er resultatet af tankemæssige abstraktioner og analytiske processer.

Samtidigt har forskning et paradoksalt element, fordi man leder efter noget, som man først ved, hvad er, når man finder det. Man leder netop efter noget nyt. Ofte har vi kun en meget vag idé om, hvad problemet er, dvs. hvad det er, som vi ikke ved, men som vi kan komme til at vide, når vi har foretaget analysen. På den måde er videnskabelig problemløsning tæt forbundet med det problem at skabe et problem. Dermed kan vi sige, at en del af det videnskabelige problem er at transformere et ukendt problem til et kendt problem og dermed blive i stand til at løse det. Dette er illustreret af den meget almindelige erfaring, at man arbejder på sin problemformulering, mens man er i gang med sin analyse. Så man svinger mellem at formulere og løse sit videnskabelige problem. Jo mere man forstår, jo bedre forstår man også, hvori problemet består.

\section{Sammenfattende om ledelses- og vidensproblemer}

Vi kan nu kort sammenfatte nogle af forskellene på og lighederne mellem ledelses- og vidensproblemer. Ledelsesproblemer er problemer, hvor den uønskede tilstand handler om handlinger. Nogen handler eller kommunikerer på en uønsket måde. I et ledelsesperspektiv er det meget ofte konkrete andre - typisk medarbejdere, ledere i andre afdelinger, andre faggrupper osv. - der handler, undlader at handle eller taler om tingene på en måde, der i lederens øjne ses som uønskede. Det kan dog være vanskeligt præcist at definere og afgrænse den uønskede tilstand nærmere. Udspringer problemet $f x$ af en gruppe aktørers handlinger eller snarere af de strukturer, som er med til at forme gruppens handlinger? Transformationen består af en forandring i disse handlinger, mens barriererne for transformationen kan have forskellig karakter (manglende ressourcer, 
interessekonflikter mm). En af barriererne kan være manglende viden om, hvordan man kan realisere transformationen.

Ledelsesproblemer formuleres typisk med sætningen "hvordan kan vi..." eller "hvordan kan jeg...". Denne sætning indikerer på samme tid både en handlingsorientering og fremtidsorientering, hvor svaret handler om, hvad man skal gøre i fremtiden. Det sigter mod en fremtidig forandring. Ledelsesproblemer formuleres ofte bagfra, altså fra løsningssiden. De ekspliciterer den ønskede, fremtidige, tilstand, mens den uønskede tilstand kan være implicit. Vidensproblemer er problemer, hvor den uønskede tilstand handler om mangelfuld, modsætningsfuld viden eller modsætning mellem viden og iagttagelser. Det kræver som regel arbejde at finde ud af og formulere, hvad det er, vi ikke ved. Transformationen består i en bevægelse fra denne mangelfulde viden til ny viden. Barrierer for denne transformation kan være manglende data, mangel på ideer, epistemologiske blokeringer (antagelser som begrænser den mulige forståelse - $\mathrm{fx}$ at jorden er centrum i universet) med mere. Hvor ledelsesproblemer retter sig mod fremtiden, er vidensproblemer typisk nutids- eller fortidsorienterede. Vidensproblemer kan også have en fremtidsdimension, hvis de er interesserede $i$ at etablere viden om kausale sammenhænge, som også vil gælde i fremtiden. Men disse kausale sammenhænge kan kun etableres ved at se på, hvad der allerede er sket - altså i fortiden. Løsningen af vidensproblemer er dermed i sig selv ikke lig med en forandring (bortset fra en mulig forandring i den gældende viden).

Vi kan sammenfatte nogle karakteristika ved ledelses- og vidensproblemer med nedenstående skema:

\begin{tabular}{|c|c|c|}
\hline Variable & Ledelsesproblemer & Vidensproblemer \\
\hline Uønsket tilstand & $\begin{array}{l}\text { Handlinger, herunder } \\
\text { sproglige handlinger } \\
\text { Kan være "ill-defined" }\end{array}$ & $\begin{array}{l}\text { Manglende viden } \\
\text { Ofte "ill-defined" }\end{array}$ \\
\hline Barrierer & $\begin{array}{l}\text { Manglende ressourcer, } \\
\text { Interessekonflikter, } \\
\text { Manglende handlekraft/ } \\
\text { mod/opbakning, } \\
\text { Manglende viden om/ideer } \\
\text { til hvordan man transfor- } \\
\text { merer den uønskede til } \\
\text { den ønskede tilstand }\end{array}$ & $\begin{array}{l}\text { Manglende data } \\
\text { Mangel på ideer } \\
\text { Begrænset tid } \\
\text { Epistemologiske } \\
\text { blokeringer } \\
\text { Utilstrækkelige teoretiske } \\
\text { begreber }\end{array}$ \\
\hline Transformationsmodus & $\begin{array}{l}\text { Handlinger - man løser } \\
\text { problemet ved at gøre } \\
\text { noget } \\
\text { Transformationen består i } \\
\text { en forandring }\end{array}$ & $\begin{array}{l}\text { Erkendelser - man løser } \\
\text { problemet ved at forstå } \\
\text { eller forklare noget }\end{array}$ \\
\hline Ønsket tilstand & $\begin{array}{l}\text { Består i anderledes hand- } \\
\text { linger } \\
\text { Ofte delvist kendt }\end{array}$ & $\begin{array}{l}\text { Består i ny viden } \\
\text { Som regel ukendt }\end{array}$ \\
\hline Tidlig orientering & Fremtidsorienteret & $\begin{array}{l}\text { Fortids- eller nutids- } \\
\text { orienteret }\end{array}$ \\
\hline
\end{tabular}

Tabel 1: Ledelses- og vidensproblemer 


\section{Problemer i kontekst}

Vi har indtil nu set på problemets formelle struktur og har specificeret det i forhold til to typer af problemer, nemlig ledelses- og vidensproblemer, som vi har argumenteret for er principielt og analytisk set forskellige, selvom de også er beslægtede og har klare fællestræk. Vi har indtil videre behandlet den uønskede tilstand, barrierer, transformationsformen og den ønskede tilstand som om, det er noget, der giver sig selv. Det er ikke tilfældet. Hverken ledelsesmæssige eller vidensmæssige problemer svæver rundt som isolerede problembobler. Som Ove Kaj Pedersen har udtrykt det, så kan et problem kun "udpeges i en bestemt meningsfyldt sammenhæng og i kraft af bestemte interessers mulighed for at formulere og formidle det..." (Pedersen, 1985: 68) Det skal vi se nærmere på i dette afsnit. Vi slår dermed et nyt tema an, som er sammenhængen mellem problemer og den kontekst, der gør dem meningsfulde og i den forstand altid er en forudsætning for arbejdet med problemer.

Selvom et problem per definition forudsætter en form for uvidenhed om det område, man vil undersøge, så forudsætter det samtidig også viden, fordi dette er en forudsætning for at kvalificere og afgrænse problemet, så det lader sig undersøge i praksis. Igen er der på tværs af i øvrigt meget forskellige videnskabsteoretiske positioner og samfundsvidenskabelige forskningstraditioner enighed om, at der aldrig er en direkte relation mellem virkelighed og erkendelse, og at observationer aldrig er "teorifri". Når vi betragter verden, gør vi det altid gennem et tankemæssigt og begrebsmæssigt filter, der alt efter forskningstradition fx kan kaldes "forforståelse", "mentale skemaer", "forestillingsbilleder" eller "bias". Der er tale om antagelser, som både former og farver vores betragtninger og opfattelse af det, vi ser. Det betyder, at de fænomener, vi interesserer os for - ledelsesmæssigt såvel som i en akademisk sammenhæng - ikke er givet, men konstitueres på måder, der altid kunne have været anderledes.

Dette er en pointe, der især er udfoldet i konstruktivismen, men som ikke begrænser sig til denne tradition. Konstruktivismen har gjort os opmærksomme på, at selvom fænomener fremstår som selvfølgelige eller "naturlige", så har de en tilblivelseshistorie. Vores måde at kategorisere og tale om tingene på former fænomenet (Justesen og MikMeyer, 2010: 29ff). Med andre ord får fænomener først betydning, når de indgår i en specifik kontekst, og denne kontekst er med til at sætte fænomenet og dets betydning på en særlig måde. Det er fx ikke i sig selv givet, hvad en borger, en leder, en medarbejder, en politiker osv. er - det afhænger af, hvordan iagttageren konstruerer disse som genstande. Og denne konstruktion er igen spundet ind i særlige typer sprog og kategoriseringer, diskurser, processer og netværk af institutioner.

Det samme gør sig gældende med problemer.

Hvad der kan fremstå som et problem, afhænger af den meningsmæssige kontekst, som problemet iagttages i. Det kalder på refleksion, for hvordan undgår man selv at blive 'offer' for andres meningsmæssige konstruktioner af, hvad der kan tælle som et problem? 
Den amerikanske sociolog Herbert Blumer udtrykte det på denne måde: "One can see the empirical world only through some scheme or image of it. [...]. This picture sets the selection and formulation of problems..." (Blumer, 1969: 24-25, citeret i Becker, 1998: 10). Det betyder, at problemer aldrig er givet i en bestemt form forud for identifikationen, udformningen og formuleringen af dem - selvom det måske forekommer sådan, især når det gælder ledelsesproblemer.

Konsekvensen bliver, at den løbende refleksion over, hvordan problemer afgrænses og defineres, bliver en væsentlig øvelse, både når det gælder ledelsesproblemer og vidensproblemer. På den ene side forudsætter arbejdet med problemer, at man foretager et valg og formulerer problemet på en måde, som nødvendigvis er en særlig afgræsning baseret på et bestemt sæt af antagelser om problemets karakter og genstand. På den anden side kan det være, at det viser sig, at det forståelsesmæssige sammenbrud, der ligger til grund for formuleringen af vidensproblemet, netop handler om den måde, problemet er iagttaget på, snarere end om det iagttagede fænomen.

Vi kan illustrere pointen med et eksempel på en type af ledelsesproblem, som har optaget flere af de ledere, vi har mødt på masteruddannelserne, og som de har ønsket at undersøge akademisk. Det er en type af problem, som tager afsæt i en undren over mangelfuld implementering af centralt besluttede strategier, ledelsesgrundlag eller lignende. De antagelser, der ligger til grund for denne undren over mangelfuld implementering, er måske en forestilling om, at en organisation er et velordnet hierarki med faste koblinger mellem lagene og med organisatoriske enheder, som følger og forstår strategier, målsætninger og programmer på samme måde, hvis implementeringsprocessen er rationelt planlagt og gennemført. Hvis man derimod abonnerer på et organisationsbegreb, hvor der i samme organisation er flere forskellige interesser, rationaler og måder at iagttage og fortolke organisationens virke på - hvis man med andre ord har flerstemmighed og løse koblinger som afsæt - så er det ikke mærkeligt, at strategier ikke implementeres sådan som topledelsen har besluttet. Man vil tværtimod netop forvente dekobling eller løse koblinger, bl.a. fordi man vil forvente, at der er mange rationaler på spil samtidigt - hvor det ikke er muligt at honorere dem alle på samme niveau på samme tid. Med dette organisationsbegreb som forståelsesramme vil man i stedet undre sig, hvis strategier, ledelsesgrundlag osv. faktisk tages for pålydende og implementeres i noget, der minder om et et-til-et forhold.

I eksemplet ovenfor er det en særlig organisationsforståelse, som har betydning for, hvad der kan fremstå som et problem og som noget, man undrer sig over. I andre tilfælde kan det i højere grad være politiske strategier, som ligger bag, hvad der fremstår som et problem. Sygefravær kan fx iagttages som udtryk for dårlig arbejdsmoral og som et individuelt problem - eller det kan iagttages som udtryk for stressende arbejdsforhold, dårlig ledelse osv. Forskellige kontekster kan således udpege det samme fænomen som vidt forskellige problemer. Ofte er den meningsmæssige kontekst for udpegningen af både ledelses- og vidensproblemer usynlig eller ubemærket. Ikke desto mindre kan det være en god idé at overveje, hvilke antagelser der ligger implicit i udpegningen af et problem som et problem.

\section{Ligesom praktiske problemer er spundet ind i diskurser og interesser, således er videnskabelige problemer det også.}


Vidensproblemer formuleres i en ramme af teoretiske antagelser og metoder. Disse teoretiske antagelser svæver igen ikke i et tomrum, men er på forskellig vis relateret til deres samfundsmæssige, historiske og kulturelle kontekst. Det kan handle om finansieringsformer (nogle typer af videnskabelige problemer har lettere ved at finde finansiering end andre), men det kan også handle om forståelsesformer, som hænger sammen med mere grundlæggende samfundsmæssige strukturer. I marxistiske traditioner har begrebet om ideologi fx udtrykt det forhold, at økonomiske relationer og forståelsesformer breder sig til andre områder og får betydning for, hvordan vi forstår naturen, os selv og relationer til andre. Sammenhængen mellem videnskab og samfund går dog begge veje. BI.a. har den franske idéhistoriker Michel Foucault undersøgt tilblivelsen af vores forestillinger om galskab, seksualitet og ledelse - forestillinger, som videnskabelige institutioner har været med til at skabe.

I forlængelse af ovenstående kan vi nu tegne den udvidede problemfigur på følgende måde:

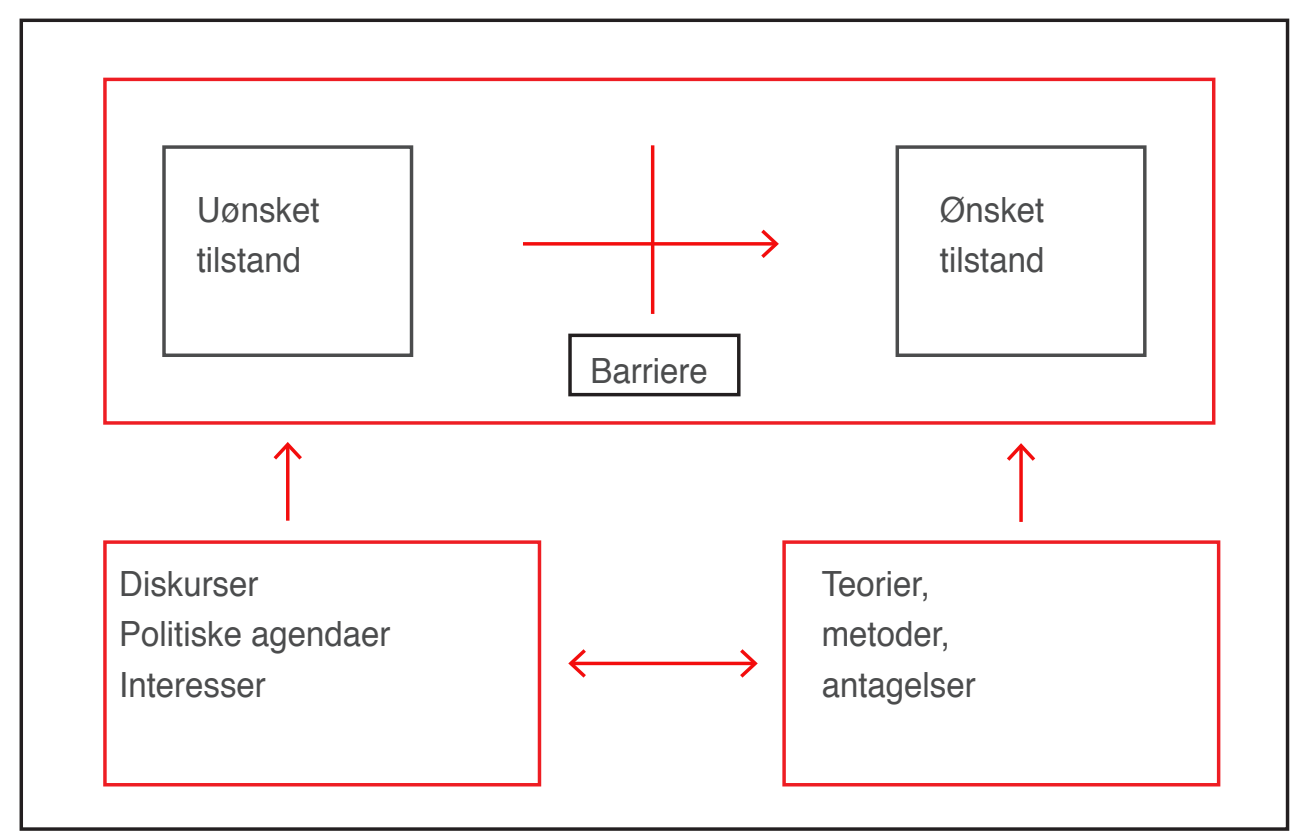

Figur 3: Udvidet model for problem

Figuren viser, at problemer ikke svæver frit rundt som isolerede og uafhængige enheder, men altid er problemer i en særlig meningsmæssig sammenhæng. Den meningsmæssige sammenhæng kan være af samfundsmæssig art (og bestå af politiske dagsordener eller mere indirekte i form af diskurser med sammenfletninger af viden og magt), men den kan også være af mere teoretisk art. Forskellige teoretiske perspektiver tematiserer det samme fænomen (og det tilhørende problem) forskelligt. Samtidig er heller ikke videnskabelige teorier og perspektiver løsrevet fra en samfundsmæssig sammenhæng. Også teorier er vævet sammen med interesser og magt - bl.a. magt til at udpege nogle problemer som relevante og andre som irrelevante. 


\section{At koble ledelsesproblemer og vidensproblemer}

Som det fremgår af tabel 1, så er der mange forskelle på ledelses- og vidensproblemer. Der, hvor de nærmer sig hinanden, er i forhold til barrierer. Netop manglende viden kan være en af barriererne i den ledelsesmæssige transformation af en uønsket til en ønsket tilstand - man ved simpelthen ikke, hvordan man løser problemet. Det kan med andre ord gælde om at få formuleret denne manglende ledelsesmæssige viden på en måde, så det bliver muligt at arbejde med den som et vidensproblem. Den centrale opgave i koblingen af ledelses- og vidensproblem er at formulere et vidensproblem, hvis løsning kan hjælpe en til at overkomme barriererne i ens ledelsesproblem. Vi har nedenfor formuleret fem tommelfingerregler, som kan guide arbejdet med den opgave.

Det er netop tommelfingerregler og ikke rigide forskrifter. Kombinationen af ledelses- og vidensproblem rummer et kreativt element, fordi det ikke er muligt logisk at deducere sig frem til, hvilket vidensproblem man skal arbejde med for at løse sit ledelsesproblem. Ledelses- og vidensproblemer smelter ikke sammen, og der ligger et spring i bevægelsen fra det ene til det andet problem. Det er et spring, som man ikke kommer uden om, men samtidig et spring, som man kan kvalificere ved at tænke sig om. Det handler også om at få gode ideer i forhold til de specifikke problemer og mulige belysninger af dem. At konstruere gode ideer kan være hårdt arbejde, der kan hjælpes på vej af nedenstående tommelfingerregler.

\section{1. tommelfingerregel: Skeln mellem videns- og ledelsesproblem}

Dette er den vigtigste regel. Først ved at skelne analytisk mellem videns- og ledelsesproblemer kan man stille spørgsmålet om, hvordan man kan få dem koblet på en frugtbar måde. Man undgår derved frustrationerne over ikke at kunne svare direkte på sin ledelsesmæssige problemstilling med videnskabelige midler. Samtidig vinder man friheden til at undersøge sit vidensproblem på dets egne præmisser.

Nedenstående tager afsæt i, at man starter med et ledelsesproblem, hvilket er det mest almindelige på MPG og tilsvarende lederuddannelser. Men hvis man i stedet starter med et vidensproblem ( $\mathrm{fx}$ fordi man er blevet interesseret i et emne i løbet af undervisningen), så kan man forsøge at kvalificere problemet dels ved at analysere det med den skitserede model, dels ved at stille spørgsmålet: Med henblik på hvilket ledelsesproblem skal dette undersøges? At overveje dette kan erfaringsmæssigt være med til at give arbejdet med vidensproblemet en tydeligere retning.

\section{2. tommelfingerregel: Analysér ledelsesproblemet ud fra den skitserede model over problemets anatomi}

Man kan her stille spørgsmål som:

Den uønskede tilstand: Hvori består den? For hvem er den uønsket? Hvordan er jeg selv involveret i problemet? Er det en ny tilstand? Er det et overfladeproblem, som snarere er afledt af et andet problem (og i givet fald hvilket)? Tænk også konteksten med - hvordan hænger den uønskede tilstand sammen med fx ændrede styreformer? I hvilken meningsmæssig kontekst kan det fremstå som noget uønsket? Alle problemer kan anskues forskelligt, og forskellige kategoriseringer vil sætte problemet forskelligt. Eksperimentér med forskellige vinkler på problemet.

Barrieren: Hvad er det, du/l ikke ved, som I har brug for at vide for at kunne transforme- 
re den uønskede tilstand til den ønskede tilstand?

Den ønskede tilstand - hvori består den? Hvilke omkostninger i form af nye problemer ligger der potentielt i den ønskede tilstand?

Hvis man starter fra den ønskede tilstand, så overvej så konkret som muligt, hvori den aktuelle uønskede tilstand specifikt består.

\section{3. tommerfingerregel: Reflektér over den meningsmæssige sammenhæng, som gør problemet til et problem}

Overvej, hvordan problemet kan defineres på forskellige måder. Hvis man fx arbejder med medarbejdernes manglende motivation som problem, så formulerer man det måske i første omgang som et spørgsmål om, hvad der får medarbejderne til at arbejde, hvilket måske igen handler om deres arbejdsindsats. Men her kan man så overveje, hvilke antagelser der ligger bag (og hvilke implikationer det har) at tematisere dette fænomen på denne og ikke på en anden måde (altså at man tematiserer arbejdsindsatsen som et spørgsmål om motivation og ikke fx som et spørgsmål om arbejdsbetingelser eller lederes og medarbejderes forskellige interesser).

Man kan blive et lidt mindre let offer for andres aktuelle politiske og styringsmæssige dagsordener ved at tænke historisk. Hvordan blev den pågældende problematik tidligere diskuteret? Hvilke interesser, institutioner og diskurser har været i spil i forhold til den måde, man i dag tematiserer problematikken på? Målet er at udvide horisonten, indenfor hvilken man formulerer sit ledelsesproblem.

Man kan også reflektere over den meningsmæssige sammenhæng ved at eksperimentere med forskellige teoretiske perspektiver, hvor man definerer problemet på alternativer måder. Træk på egne og andres teoretiske ressourcer og afprøv, hvordan forskellige teoretiske perspektiver sætter forskellige problematikker. Refleksioner over den meningsmæssige sammenhæng kan hurtigt blive omfattende og kalde på større analyser. Nogle gange er det givtigt at gå videre ad denne vej, andre gange må man stoppe sig selv og holde fast i den oprindelige problematik.

\section{4. tommerfingerregel: Fokusér på barrieren for transformationen}

Hvad er det, man ikke ved, som man har brug for at vide for at kunne transformere fra uønsket til ønsket tilstand? Her gælder det om gå fra, hvad der er blevet kaldt 'unknown unknowns' (eller unk unks) til 'known unknowns', så man ved, hvad det er, man ikke ved. Begrebet om transformationsviden er nyttigt i diskussionen af forholdet mellem ledelsesproblem og vidensproblem. Det peger nemlig på et vidensproblem i ledelsesproblemet. Det peger på spørgsmålet om, hvad det er, jeg skal vide, for at kunne transformere den uønskede situation til den ønskede situation. Det rækker over mod spørgsmålet om, hvad jeg skal undersøge, hvad jeg skal producere viden om for at kunne løse mit ledelsesproblem. Samtidig skal det bemærkes, at det at vide, hvordan et problem skal løses, ikke er identisk med selve løsningen af det. Transformationsviden er en nødvendig, men ikke tilstrækkelig del af løsningen af problemet. Som oftest kræver løsningen af problemet en egentlig handling.

\section{5. tommelfingerregel: Overvej, hvilken viden der vil gøre det muligt at bevæge sig fra uønsket til ønsket tilstand}

I forhold til ledelsesproblemet mangler man typisk viden om, hvad man skal gøre. Det 
kan man ikke få direkte svar på ved at løse et vidensproblem. Men man kan overveje, hvilken viden, det er muligt at producere, som samtidig kan være relevant information i forhold til den manglende viden, der udgør en barriere for transformationen af ledelsesproblemet. Hvis ledelsesproblemet fx er, at man skal implementere et nyt IT-system - vel vidende, at den slags implementeringer har det med at gå galt - så vil en del af barrieren for en vellykket løsning af problemet typisk være, at man ikke ved, hvordan man skal gøre det. Her kunne man formodentlig få relevant information ved at se på, hvordan tilsvarende systemer er blevet implementeret - og med hvilket resultat. Man ville ikke få svar på, hvordan man skulle gøre det, men man ville få en bedre forståelse for mulige problemer og potentialer i processen.

\section{Referencer}

Agre, G. P., (1982). The Concept of Problem. Educational Studies, 13 (2), 121-142.

Alvesson, M. og Kärreman, D. (2005). At arbejde med mysterier og sammenbrud: Empirisk materiale som kritisk samtalepartner i teoriudvikling. I Järvinen, M. og Mik-Meyer, N. (red.). Kvalitative metoder $i$ et interaktionistisk perspektiv (s. 121-144). København: Hans Reitzels Forlag.

Becker, H. S. (1998). Tricks of the trade. Chicago and London: The University of Chicago Press.

Booth, W. C., Colomb, G. C. og Williams, J. M. (2003). The Craft of Research, 2. udgave. Chicago: The University of Chicago Press.

Dewey, J. (1910/2012). How we Think. Boston, New York, Chicago: D.C Heath \& Co., Publishers.

Justesen, L. og Mik-Meyer, N. (2010). Kvalitative metoder i organisations-og ledelsesstudier. København: Hans Reitzels Forlag.

Mach, E. (1905/2015). Erkenntnis und Irrtum; Skizzen zur Psychologie der Forschung. Willingen-Schwenningen: Nexx-Verlag.

Pedersen, K. (2015). Problemstilling og problemformulering. I Bitsch Olsen, P. og Pedersen, K. (red.) Problemorienteret projektarbejde - en værktøjsbog. (s. 27-50), 4. udgave. Roskilde: Roskilde Universitetsforlag.

Pedersen, O.K (1985). Nok et problem. I Ingemann. J. H. (red.) Projektarbejdets metodik - en antologi om videnskabsteoretiske problemer i det problemorienterede, tværvidenskabelige arbejde (s. 63-105). RUC: Forlaget samfundsøkonomi og planlægning.

Popper, K. (1972). Conjectures and refutation: The Growth of Scientific Knowledge. 4. udgave. London: Routledge.

Smith, G. (1989). Defining Managerial Problems: A Framework for Prescriptive Theorizing. Management Science, 35(8), 963-981.

Schmidt, J. (2011). What is a problem? Poiesis \& Praxis, 7(4), 249-274.

Scholz R. W. (2011). Environmental literacy in science and society: from knowledge to decisions. Cambridge: Cambridge University Press.

Weber, M. (1904/2003). Udvalgte tekster. Bind 1. København: Hans Reitzels Forlag. 